\title{
MS14-P22 | SYNTHESIS AND CRYSTAL STRUCTURE OF NEW ALKALI CHALCOGENIDO MANGANATES/INDATES
}

Langenmaier, Michael (Albert-Ludwigs-Universität Freiburg, Freiburg, GER)

In the system $A-F e-Q$ mixed-valent alkali chalcogenido ferrates are well known [1-3]. Recently we mimiced an equivalent mixed-valent state for $\mathrm{Mn}$, by a partially replacement of $\mathrm{Mn}$ (II) by $\ln (\mathrm{III})$ [4]. Now we present newly obtained metalates $\mathrm{Na}_{12} \mathrm{MnIn}_{2} Q_{10}\left(Q=S\right.$, Se) $(1,2)$ as well as so far unknow indates $\mathrm{K}_{6} \ln \mathrm{n}_{2} \mathrm{~S}_{6}(3)$ and $\mathrm{K}_{6} \ln \mathrm{S}_{4.5}$ (4). In all these compounds there are $\left[M Q_{4}\right]$ tetrahedra, either isolated or connected via edges.

The compounds were obtained by heating stoichiometric mixtures of the elements or binary phases at $T_{\max }=1200 \mathrm{~K}$. All structures were determined by means of X-ray single crystal diffraction.

The compounds $1 \& 2$ crystallize in the space group $P 2_{1} / \mathrm{m}$ and contain isolated $\left[\ln Q_{4}\right]^{5-}$ tetrahedra as well as $\left[M_{2} Q_{6}\right]^{7-}$ dimers with $M=M n$ and In.

$\mathrm{K}_{6} \mathrm{In}_{2} \mathrm{~S}_{6}$ crystallizes in $P 2_{1} / c$. Though not isotypic, it shows similarities to $\mathrm{K}_{6} \mathrm{Fe}_{2} \mathrm{~S}_{6}$ [5] with its $\left[\ln _{2} \mathrm{~S}_{6}\right]^{6-}$ dimers of edgesharing tetrahedra.

$\mathrm{K}_{6} \mathrm{InS}_{4.5}$ crystallizes in $P 6_{3} m c$ and is almost isotypic to $\mathrm{K}_{6} \mathrm{MnS}_{4}$ [6]. The only difference is an additional $\mathrm{S}$ position, which is only partially occupied.

[1] P. Stüble, S. Peschke, D. Johrendt, C. Röhr, J. Solid State Chem., 258, 416, (2018).

[2] P. Stüble, A. Berroth, C. Röhr, Z. Naturforsch. B, 71, 485, (2016).

[3] K. O. Klepp, H. Boller, Monatsh. Chem., 112, 83, (1981).

[4] M. Langenmaier, J. Brantl, C. Röhr, Z. Kristallogr. Suppl., 39, 68 (2019).

[5] M. Schwarz, M. Haas, C Röhr, Z. anorg. allg. Chem., 639, 360 (2013).

[6] W. Bronger, H. Balk-Hardtdegen, Z. Anorg. Allg. Chem., 574, 89 (1989). 